\title{
ORAL HEALTH STATUS AND ASSOCIATED FACTORS IN A SUBPOPULATION OF TURKISH PATIENTS
}

\section{ABSTRACT}

Objectives: Understanding the oral health behavior and knowing oral health status of a community in order to facilitate the development of satisfactory dental public health preventive program. In this context, the purpose of this study is to investigate oral health behaviour of Turkish community who live in Usak province besides and to evaluate CPITN and DMFT index scores according to age, gender and education level.

Materials and Methods: A face to face questionnaire was conducted for 2412 subjects who were divided into six age groups to understand their oral health behavior. Periodontal measurements, and dental caries were applied by three calibrated expert researchers for all teeth except the third molar.

Results: Healthy periodontal tissue only existed in 153 (10.05\%) individuals of 1521 dentate participants. The mean DMFT value observed was $16.98 \pm 6.62$. By aging, being male and having low education level, mean DMFT and CPITN scores showed an upward trend. $10.26 \%$ of the participants informed that they did not brush their teeth and $92.55 \%$ of them stated that they did not floss their teeth. Most of the participants $(83.25 \%)$ informed that they visited a dental clinic only in emergency and pain.

Conclusions: The mean DMFT and CPITN scores increase in accordance with aging, low education and being male. Low flossing frequency, low prevalence of tooth brushing and low frequency of going to the dentist regularly were observed at the end of the study.

Keywords: Age groups, oral health, toothbrushing, dental floss, education.
ORCID IDs of the authors: F.K. 0000-0002-9899-3316 A.D. $0000-0003-4130-2526$ U.Y. 0000-0001-8080-2932

Department of Periodontology, Faculty of Dentistry, Usak University Usak Turkey

How to Cite: Karaaslan F, Dikilitaş A, Yiğit U. Oral Health Status and Associated Factors in a Subpopulation of Turkish Patients. Cumhuriyet Dent J 2019;22:2:

Department of Periodontology, Faculty of Dentistry, Usak University, Usak Turkey.

Phone: +90 05538721783 E-mail: fatih.karaaslan@usak.edu.tr 


\section{INTRODUCTION}

Oral health is a critical factor in general wellness and has an extensive impact on a person's wellbeing and quality of life. Poor oral health can lead to difficulties in speaking, chewing and swallowing. ${ }^{1}$ Furthermore, oral diseases can have an influence on some systemic diseases and health conditions. $^{2}$ The main basis of oral health evaluation is the examination of incidence and frequency of dental caries and periodontal status. ${ }^{3}$

Dental caries and periodontal diseases can affect all the population throughout the lifespan which are multifactorial diseases with many risk factors contributing to their initiation and progression. ${ }^{4}$ Periodontal diseases and dental caries are associated with socio-demographic factors such as age, sex, education, stress, smoking and oral hygiene practices. ${ }^{5}$

Periodontal diseases, one of the most widespread illnesses of humanity, destroy supporting tissues around the teeth. ${ }^{6}$ The prevalence of the periodontal disease varies in different regions of the world, and this disease affects more than 537 million people worldwide. ${ }^{7}$ The Community Periodontal Index of Treatment Needs (CPITN) is used to record population periodontal status and treatment needs. ${ }^{8}$ The primary clinical argument for the diagnosis of the periodontal diseases through the CPITN is probing depth which is the most rational definition for the operational features ascertained in epidemiologic periodontal studies. ${ }^{9}$

Dental caries is a localized destruction of dental hard tissues by acidic output from bacterial fermentation. ${ }^{10}$ Dental caries is a process of disease that ranges from subclinical changes to damage with obvious cavitation. ${ }^{11}$ Epidemiological studies of caries utilize the decayed, missing and filled teeth (DMFT) index as a sign of the cumulative outcome of caries on permanent teeth. ${ }^{12}$

Understanding of regional behavior and care conformity can lead local public health practitioners to plan and support oral health programs. Thus, this study seeks to determine the oral hygiene habits, frequency of visiting dentist and epidemiological profile of the oral health as well as to observe demographic and other indicators associated with oral disease of the general public in a Turkish city with the aim of developing satisfactory dental public health preventive programs.

\section{MATERIALS AND METHODS}

This study was carried out at the Faculty of Dentistry in Usak University. The participants were informed about the purpose of the investigation and they signed the consent form. 2412 patients who were over 18 years-old were included in the study. The research was conducted according to Helsinki Declaration and ethical permission was procured from the Local Ethical Committee of Usak University For Non-invasive Clinical Trials (Registration No: 104-06-13).

Before the clinical examination subjects filled out a questionnaire that was designed by an experienced research team. Personal data from each subject was collected through individual interviews and included demographic information, behavior and personal habits to oral health.

All study subjects were examined clinically to evaluate periodontal and dental status for all teeth except the third molar. Edentulous subjects were not included in the periodontal status analysis.

Periodontal examination was carried out according to recommendation of the World Health Organization (WHO) periodontal probe for using the CPITN. ${ }^{13}$ The index teeth $(17,16,11,26,27$, $47,46,31,36$ and 37) were evaluated for each individual. In the presence of fewer than two functional teeth, the subjects were classified as edentulous and not included in the study. Subjects with no teeth, or teeth that could not be examined for various reasons were excluded. All teeth in the subjects were examined according to the absence of index teeth and the highest score was recorded as the sequencer score. According to which tooth showed the worst condition, each subject was given a grade and registered according to the highest recording. Each subject was entitled as either healthy (score 0), bleeding (score1), calculus detected (score 2), pockets of 4-6 mm 
(score 3) and $6 \mathrm{~mm}$ or deeper pockets (score 4) according to the highest score at the index teeth. ${ }^{17}$ The epidemiological profile of dental caries was evaluated according to the norm advised by the WHO using DMFT index. ${ }^{14}$ Caries at cavitation level is a current WHO standard for detecting caries and it was used for determining the permanent tooth decay. ${ }^{15}$

Periodontal measurements and registrations were applied by three expert researchers. Calibration between the researchers and selfcalibration of the researchers ensured for the standardization of measurements in equal clinical conditions. Intra-examiner reproducibility was evaluated on four subjects. Intraclass correlation coefficient (ICC) was 0.93 for the first researcher, 0.94 for the second researcher and 0.91 for the third researcher. The calibration of inter-examiner reproducibility was performed on ten subjects. The first and the second measurements on subjects were compared with each other to evaluate the compatibility of three researchers. The compliance level of the researchers in the first measurement was $91.8 \%$ and the compliance level in the second measurement was $92.2 \%$.

Data analysis was performed by using the software Statistical Package version 17.0 (SPSS Inc., Chicago, IL, USA). Kolmogorov-Smirnov and Shapiro Wilks tests were used to investigate for checking the normality of data. Nonparametric Mann Whitney U and Kruskal Wallis-H Tests were used because the assumption of normality was violated. The Chi Square test was used to evaluate the relationships between the parameters. The statistical significance level for all tests was set at 0.05 .

\section{RESULTS}

The distribution of individuals according to age, gender and education are shown in Table 1. A total of 2412 subjects, $816(33.80 \%)$ male and $1596(66.20 \%)$ female, were included in the study. The majority of the participants had the primaryschool education level (50.5\%). Participants were divided into six age groups and the distribution shows that the most common age group was 55-64 years $(18 \%)$ followed by $\geq 74$ year-old $(17.70 \%)$.

Table 1. Demographic information (age, gender, education level)

\begin{tabular}{cccc}
\hline & n & \% \\
\hline & $\mathbf{1 8 - 3 4}$ & 415 & 17.2 \\
Age Groups & $\mathbf{3 5 - 4 4}$ & 422 & 17.5 \\
& $\mathbf{4 5 - 5 4}$ & 320 & 13.3 \\
& $\mathbf{5 5 - 6 4}$ & 434 & 18.0 \\
& $\mathbf{6 5 - 7 4}$ & 392 & 16.3 \\
& $\mathbf{7 4}$ & 429 & 17.7 \\
Education & Primary school & 1219 & 50.5 \\
& High school & 804 & 33.3 \\
\multirow{2}{*}{ Gender } & Universty & 389 & 16.2 \\
& Male & 816 & 33.8 \\
\hline
\end{tabular}

$\mathrm{n}$ Number of the patients \% Percentage

The incidences of CPITN scores of individuals according to age, gender and education are displayed in Table 2. Healthy periodontal tissue only existed in 153 (10.05\%) individuals of 1521 dentate participants. The prevalence of periodontal disease (Codes $3+4$ ) was $54.83 \%$. The proportion of excluded sextants (fewer than 2 teeth) were importantly higher in subjects aged $\geq$ 74 years $(58.74 \%)$ followed by aged $65-74$ year old $(58.41 \%)$. 
Table 2. CPITN scores of individuals according to age, gender and education ( $\mathrm{n} / \%)$

\begin{tabular}{|c|c|c|c|c|c|c|c|c|c|}
\hline & & $\mathbf{n}$ & 0 & 1 & 2 & 3 & 4 & c & p value \\
\hline \multirow{7}{*}{ Age Groups } & $18-34$ & 360 & $41 / 11.4$ & $57 / 15.83$ & $76 / 21.11$ & $87 / 24.16$ & $99 / 27.5$ & \multirow{6}{*}{31.21} & \multirow{7}{*}{$0.001 *$} \\
\hline & $35-44$ & 305 & $33 / 10.81$ & 49/16.06 & $59 / 19.34$ & $81 / 26.55$ & $83 / 27.21$ & & \\
\hline & $45-54$ & 251 & $31 / 12.35$ & $43 / 17.13$ & $49 / 19.52$ & $57 / 22.72$ & $71 / 28.28$ & & \\
\hline & $55-64$ & 265 & $28 / 10.59$ & $47 / 17.73$ & $57 / 21.50$ & $64 / 24.15$ & $69 / 26.03$ & & \\
\hline & $65-74$ & 163 & $11 / 6.76$ & $19 / 11.65$ & $23 / 14.11$ & $41 / 25.15$ & $69 / 42.33$ & & \\
\hline & $\geq 74$ & 177 & $9 / 5.11$ & $21 / 11.86$ & $34 / 19.20$ & $51 / 28.81$ & $62 / 35.02$ & & \\
\hline & Total & 1521 & $153 / 10.05$ & $236 / 15.51$ & $298 / 19.59$ & $381 / 25.04$ & $453 / 29.81$ & 1521 & \\
\hline \multirow{3}{*}{ Education } & Primary school & 617 & $17 / 2.75$ & $97 / 15.72$ & $132 / 21.39$ & $165 / 26.74$ & $206 / 33.4$ & & \multirow{4}{*}{$0.001 *$} \\
\hline & High school & 558 & $46 / 8.24$ & $87 / 15.59$ & $107 / 19.17$ & $139 / 24.91$ & $179 / 32.09$ & 141.75 & \\
\hline & Universty & 346 & $90 / 26.01$ & $52 / 15.02$ & $59 / 17.05$ & $77 / 22.25$ & $68 / 19.67$ & & \\
\hline \multirow{4}{*}{ Gender } & Total & 1521 & $153 / 10.05$ & $236 / 15.51$ & $298 / 19.59$ & $381 / 25.04$ & $453 / 29.81$ & 1521 & \\
\hline & Male & 380 & $31 / 8.15$ & $33 / 8.68$ & $82 / 21.57$ & $105 / 27.63$ & $129 / 33.97$ & & \multirow{3}{*}{$0.001 *$} \\
\hline & Female & 1141 & $122 / 10.69$ & $203 / 17.79$ & $216 / 18.93$ & $276 / 24.18$ & $324 / 28.41$ & 22.38 & \\
\hline & Total & 1521 & $153 / 10.05$ & $236 / 15.51$ & $298 / 19.59$ & $381 / 25.04$ & $453 / 29.81$ & 1521 & \\
\hline
\end{tabular}

In the 18-34 year-aged group, 41(11.4\%) individuals had no periodontal disease. However, in the subjects aged $\geq 74$ year old, only $9(5.11 \%)$ individuals were healthy. The proportion of shallow pockets (pockets depth 4-6mm) and deep pockets (pockets depth $>6 \mathrm{~mm}$ ) in the subjects aged $\geq 74$ year old was $63.83 \%$. There was a statistically significant relationship between age groups and CPITN (Chi-square test, $\mathrm{p}<0.05$ ). CPITN index increased as the ages of the participants increased.

There was a prominent association between CPITN and schooling (Chi-square test, $\mathrm{p}<0.005$ ). The outcome indicated that individuals with university education had less bleeding (Code 1), less calculus (Code 2), less shallow and deeper pockets (Codes 3+4) than individuals with primary and high education level.

There was a significant difference between CPITN and gender. More females (10.69\%) than males $(8.15 \%)$ were periodontally healthy (Code 0 ), and the prevalence of periodontal disease
(Codes 3+4) was significantly higher in males $(61.6 \%)$ than in females $(52.59 \%)$, and these differences were significant (Chi-square test, $\mathrm{p}<0.05)$.

DMFT score according to age, gender and education is shown in Table 3 and 4. The mean DMFT value observed was $16.98 \pm 6.62$. With aging, the mean DMFT showed an upward trend and increased from 11.97 in 18-34 year-olds to 23.60 in $\geq 74$ year-olds. The differences in mean DMFT between the age categories were statistically significant (Kruskal-Wallis test, $\mathrm{p}<0.05)$. The mean DMFT value was importantly higher in males (19.16) than in females (15.86) and these differences were significant (MannWhitney test, $\mathrm{p}<0.05)$. The mean DMFT value was 10.69 in subjects with university education level, was $14.83 \%$ in subjects with high school education level and 20.40 in subjects with primary school education level. All these differences were statistically significant (Kruskal-Wallis test, $\mathrm{p}<0.05$ ).

Table 3. DMFT score according to age, gender and education

\begin{tabular}{|c|c|c|c|c|c|}
\hline & & $\mathbf{n}$ & Mean \pm sd & $\mathrm{C}$ & $\mathrm{p}$ value \\
\hline \multirow{6}{*}{ Age groups } & $18-34$ & 415 & $11.97 \pm 4.84$ & \multirow{6}{*}{1038.967} & \multirow{7}{*}{$0.001 *$} \\
\hline & $35-44$ & 422 & $13.30 \pm 4.75$ & & \\
\hline & $45-54$ & 320 & $13.99 \pm 4.62$ & & \\
\hline & $55-64$ & 434 & $16.59 \pm 5.39$ & & \\
\hline & $65-74$ & 392 & $21.85 \pm 5.17$ & & \\
\hline & $\geq 74$ & 429 & $23.60 \pm 4.72$ & & \\
\hline \multirow{5}{*}{ Education } & Total & 2412 & $16.98 \pm 6.62$ & & \\
\hline & Primary school & 1219 & $20.40 \pm 5.95$ & \multirow{4}{*}{786.312} & \multirow{4}{*}{$0.001 *$} \\
\hline & High school & 804 & $14.83 \pm 5.38$ & & \\
\hline & Universty & 389 & $10.69 \pm 3.97$ & & \\
\hline & Total & 2412 & $16.98 \pm 6.62$ & & \\
\hline \multirow{4}{*}{ Gender } & & & & $\mathbf{Z}$ & \multirow{4}{*}{$0.001 *$} \\
\hline & Male & 816 & $19.16 \pm 6.41$ & \multirow{3}{*}{-11.967} & \\
\hline & Female & 1596 & $15.86 \pm 6.45$ & & \\
\hline & Total & 2412 & $16.98 \pm 6.62$ & & \\
\hline $\mathrm{n}$ Number of the patients & sd Standard deviation & c Chi-square test & z Mann-Whitney test & & \\
\hline
\end{tabular}


Table 4. Proportion and number of decay, missing, filling teeth according to age, gender and education

\begin{tabular}{|c|c|c|c|c|c|c|}
\hline & & D & $\mathbf{M}$ & $\mathbf{F}$ & Total & DMFT index \\
\hline \multirow{7}{*}{ Age Groups } & $18-34$ & $521(30.61 \%)$ & $1776(35.74 \%)$ & $1671(33.65 \%)$ & 4968 & 11.97 \\
\hline & $35-44$ & $1463(26.06 \%)$ & $2563(45.66 \%)$ & $1587(28.28 \%)$ & 5613 & 13.30 \\
\hline & $45-54$ & $1204(26.88 \%)$ & $2141(47.81 \%)$ & $1133(25.31 \%)$ & 4478 & 13.99 \\
\hline & $55-64$ & $1463(20.31 \%)$ & $4319(59.97 \%)$ & $1419(19.72 \%)$ & 7201 & 16.59 \\
\hline & $65-74$ & $1603(18.70 \%)$ & $5587(65.20 \%)$ & $1378(16.1 \%)$ & 8568 & 21.85 \\
\hline & $\geq 74$ & $2566(25.32 \%)$ & $6474(63.89 \%)$ & $1092(10.79 \%)$ & 10132 & 23.61 \\
\hline & Total & $9820(23.97 \%)$ & $: 2860(55.8 \%)$ & $8280(20.22 \%)$ & 40960 & 16.98 \\
\hline \multirow{3}{*}{ Education } & Primary school & $4783(19.22 \%)$ & $15872(63.8 \%)$ & $4219(16.98 \%)$ & 24874 & 20.40 \\
\hline & High school & $3318(27.81 \%)$ & $5769(48.36 \%)$ & $2840(23.83 \%)$ & 11927 & 14.83 \\
\hline & Universty & $1719(41.33 \%)$ & $1219(29.30 \%)$ & $1221(29.37 \%)$ & 4159 & 10.69 \\
\hline \multirow{4}{*}{ Gender } & Total & 9820 & 22860 & 8280 & 40960 & \\
\hline & Male & $4057(25.94 \%)$ & $7863(50.27 \%)$ & $3719(23.79 \%)$ & 15639 & 19.16 \\
\hline & Female & $5763(22.75 \%)$ & $14997(59.22 \%)$ & $4561(18.03 \%)$ & 25321 & 15.86 \\
\hline & Total & 9820 & 22860 & 8280 & 40960 & \\
\hline
\end{tabular}

D Decay $\quad$ M Missing F Filling

Oral health attitudes are shown in Table 5. $10.26 \%$ of the participants informed that they did not brush their teeth. However, $24.25 \%$ of them indicated that they brushed their teeth twice a day or more. Of all the participants, $92.55 \%$ stated that they did not floss their teeth. Most of the participants $(83.25 \%)$ informed that they visited a dental clinic only in emergency and pain. Almost half of the participants $(46.64 \%)$ indicated that they were changing their tooth brushes at every 3 months. Among individuals $53.78 \%$ of them stated that they had no periodontal treatment before. The prevalence of self reported halitosis was $58.74 \%$. $56.26 \%$ of all participants reported themselves as being non-smokers or occasional smokers.

Table 5. Oral health behavior of participants

\begin{tabular}{|c|c|c|c|}
\hline & & $\mathbf{n}$ & $\%$ \\
\hline \multirow{5}{*}{ Tooth brushing } & Twice or more daily & 585 & 24.25 \\
\hline & Once Daily & 990 & 41.04 \\
\hline & Once every three or four days & 385 & 15.96 \\
\hline & Once a week & 205 & 8.49 \\
\hline & No Brushing & 247 & 10.26 \\
\hline \multirow{5}{*}{ Flossing } & Twice or more daily & 15 & 0.62 \\
\hline & Once Daily & 22 & 0.91 \\
\hline & Once every three or four days & 51 & 2.11 \\
\hline & Once a week & 92 & 3.81 \\
\hline & No Flossing & 2232 & 92.55 \\
\hline \multirow{5}{*}{$\begin{array}{l}\text { Dental visit } \\
\text { frequency }\end{array}$} & Every 6 months & 123 & 5.09 \\
\hline & Every year & 93 & 3.85 \\
\hline & Emergency & 2088 & 83.25 \\
\hline & Never visit before & 108 & 7.81 \\
\hline & Every 3 months & 1125 & 46.64 \\
\hline \multirow{3}{*}{$\begin{array}{l}\text { Tooth brush changing } \\
\text { frequency }\end{array}$} & Every 6 months & 510 & 21.14 \\
\hline & Every year & 525 & 21.76 \\
\hline & Using the same brush for years & 252 & 10.46 \\
\hline \multirow{2}{*}{ Periodontal therapy } & At least one periodontal treatment before & 1115 & 46.22 \\
\hline & No periodontal treatment before & 1297 & 53.78 \\
\hline \multirow{2}{*}{ Self reported halitosis } & Patients reported halitosis & 1417 & 58.74 \\
\hline & Patients reported no halitosis & 995 & 41.26 \\
\hline & Non-smoking or occasional smoking & 1357 & 56.26 \\
\hline \multirow{4}{*}{ Smoking } & $<1$ cigarette/day & 113 & 4.68 \\
\hline & 1-15 cigarettes/day & 243 & 10.74 \\
\hline & 16-24 cigarettes/day & 301 & 12.47 \\
\hline & $\geq 25$ cigarettes/day & 398 & 15.85 \\
\hline
\end{tabular}

$\mathrm{n}$ Number of the patients $\%$ percentage

\section{DISCUSSION}

In the current study, the proportion of individuals with periodontal pocket with probing depth of 4-6 $\mathrm{mm}$ was $26.55 \%$ for the age cohort $35-44$ and $25.15 \%$ in $65-74$ year-old. Probing depth $>6$ was $27.21 \%$ in $35-44$ year-old and $42.33 \%$ in $65-74$ 
year-old, which is higher than what was reported from other developing countries and the majority of European countries. ${ }^{16}$ In a study, the lowest probing depth of $\geq 4 \mathrm{~mm}$ for the 35-44 age group is found in Sweden and Spain (26\%) while the highest probing depth is detected in Lithuania and Germany (62.9\%). This rate rises to $42.7 \%$ individuals with 65-74 age group in Sweden and Spain while it rises to $68 \%$ in Germany and Lithuania with the same age group. ${ }^{17}$ In this study, the lowest probing depth of $\geq 4 \mathrm{~mm}$ for the 35-44 age group was $53.76 \%$ and $67.48 \%$ for $65-74$ age group. These results are the same as Lithuania and Germany but worse than Sweden and Spain. It was revealed that the lowest score of periodontal health (score 4) was limited to between $10 \%$ and $15 \%$ of the adult population worldwide ${ }^{18}$, whereas in Turkey, as many as $29.81 \%$ of the adult population had score 4 . The result of the current study unearthed that periodontal status in the Turkish population is worse than other developing countries.

The average DMFT was found to be 13.30 for 35-44 age group in this survey and the factor that increases the value of DMFT was the missing (M) component. In 55-64 age group, the mean DMFT was 21.85 and the factor that increases the value of DMFT was the M component again. The prevalence of DMFT score in this present national study was 16.98. The DMFT values in European countries ranged between 14 and 20 in adults and 22 to 27 in the $65-74$ age group. ${ }^{19}$ The average DMFT value in China at the age group 35-44 was 2.1 while at the age group $65-74$, this rate raises to 13.4. ${ }^{20}$ The results of this study are in line with the results of other studies done in European countries but higher than reported in China.

In this research, the widespread presence and severity of periodontal disease increased with age as reported before. ${ }^{21}$ With aging, the prevelance of periodontitis increased from $51.66 \%$ in the $18-34$ year-olds to $63.88 \%$ in the $\geq 74$ year-olds. The present study showed a positive correlation of the DMFT score with the age of the participants. The most prominent component of DMFT was the missing teeth $(35.74 \%)$ in the 18-34 age group and this ratio dramatically increased to $63.89 \%$ in the $\geq 74$ year-olds. This study has shown that people living in Turkey are at a greater risk of having few remaining teeth. In our opinion, the main reason for high DMFT and CPITN scores are associated with a lack of awareness about oral health which includes smoking, poor oral hygiene, infrequent dental visits, absence of dental treatment, etc. In addition, cumulative tissue destruction and age-related intrinsic abnormality are also reasons for missing teeth.

In this study, the prevalence of periodontal disease and sextants with pockets $>6 \mathrm{~mm}$ was significantly lower in highly educated people than less educated as it has been found. ${ }^{22-24}$ There was also a significant relationship between the individual's education level and mean DMFT. The average DMFT was 20.40 in the primary school group, whereas it was 10.69 in the university group. The proportion of missing teeth was higher in low educated group, while the proportion of filling teeth was greater in the higher educated group. This study unearthed that there was a positive association between education and oral health status. Awareness about the prominence of oral health, socio-economic status, monthly income, insurance coverage and leading healthy lifestyle seem to be correlated with better health status in high education group.

In this epidemiological study, it was found that males had worse oral health than females according to CPITN and DMFT indexes. Periodontally healthy subjects were more frequently observed in females, while males were associated with CPITN scores 3 and 4. DMFT score was 15.86 among female individuals, while it was 19.16 in male individuals. It was concluded that men were at a bigger risk for periodontal disease and tooth loss when compared with women. ${ }^{25}$ This might be explained by the fact that males have worse oral hygiene practices, higher smoking rate and less-frequent usage of oral health services. ${ }^{26}$

In this study, the prevalence of tooth brushing twice or more was $24.25 \%$ and daily once was $41.04 \% .10 .26 \%$ of the participants reported that they had no tooth brushing behaviour. The prevalence of tooth brushing was reported to be $44.4 \%$ in $\mathrm{China}^{27}$ and $31 \%$ in Jordan $^{28}$. This proportion varies between $80 \%$ and 
$89 \%$ in European countries, USA and Canada. ${ }^{29}$ The prevalence of tooth brushing in this present study was lower than what was reported in the developed countries.

$92.55 \%$ of the participants reported that they did not use dental floss in this survey. It was reported that $41 \%$ of Americans flossed their teeth at least once daily and $20 \%$ never flossed their teeth. ${ }^{30}$ Higher flossing frequencies than our findings were reported in Denmark ${ }^{31}$, Canada ${ }^{32}$ and similar inter-dental cleaning samples were reported from China ${ }^{33}$ and Saudi Arabia. ${ }^{34}$

In this study, it was revealed that $83.25 \%$ of the participants go to the dentist in case of pain and emergency and that $7.81 \%$ of them never visited a dentist before. The percentage of who go to the dentist regularly was \%8.94. In Canada ${ }^{32}$, $69 \%$ of the individuals visit the dentist regularly every year and $69.9 \%$ of the individuals visit the dentist regularly in the United States. ${ }^{35}$ Only $26.4 \%$ of the participants visit the dentist regularly in Nigeria ${ }^{36}$ and the frequency of dental visits in China $^{33}$ is reported as $28 \%$. The frequency of going to the dentist in Turkey is lower than those of developed and developing countries. The reason for this has not been known but it can be speculated that dental fear, limited access to oral health services and lack of oral health knowledge might be the contributing factors.

In our study sample, the frequency of changing tooth brush within 3 months was $46.64 \%$ and $10.46 \%$ of the participants indicated that they used the same brush for years. The average usage of brushes per capita and year in Turkey is 0.3 , while the average usage of brushes per capita and year in the UK is 2.4 and is 2.5 in Sweden. ${ }^{37}$ Tooth brush changing frequency in Turkey is lower than developed countries. Lower socioeconomic status, lack of tooth brushing habits and unconsciousness about oral health could be some reasons for this.

In this study, the evaluation of malodour is based on the subject's own perception as reported before. ${ }^{38}$ In the present study, the prevalence of self reported halitosis was $58.74 \%$ and it was higher than the findings reported in Brazil ${ }^{39}$, the USA $^{38}$ and France. ${ }^{40}$ Halitosis is a problem which is perceived in different regions of the world but the prevalence of it in Turkey is higher than developed countries. The lower frequency of tooth brushing, visiting a dentist only in case of pain and using a tooth brush more than three months can be related to the higher occurrence of halitosis.

The proportion of smoking in this study was $43.74 \%$. This rate is identified as $19 \%$ in older individuals in the United States. ${ }^{41}$ The rate of smoking between the ages of 30-39 is detected as $39 \%$, between the ages of 50-59 and it is $45 \%$ in Thailand..$^{42}$ Although the awareness of the adverse effects of smoking on health has increased in developed countries, smoking prevelance is high and it continues to increase in Turkey.

Also, it was found in the present study that $53.78 \%$ of the participants have never had any periodontal treatment before. Bad oral self-care, irregular dentist visits, low level of education and income might be connected with this result.

One of the limitations of the current study is the information obtained according to the personal evaluations of the individuals and the small number of the subjects included in the population. Besides, self-reported information is the most commonly used method of collecting answers and positive correlations were identified even if the examined community was relatively small. A future targeted screening of periodontal disease which may be considered as a public health problem and associated risk indicators would clarify the implementation of preventive programs. Community-based prevention-oriented projects should be implemented by national health authorities to improve the oral health of people from all ages.

\section{ACKNOWLEDGEMENT}

The study did not receive any financial support.

\section{CONFLICT OF INTEREST}

The authors report no conflicts of interest related to this study.

\section{Türk Populasyonunun Bir Alt Grubunda Ăğı Sağlı̆̆ı ve İlişkili Faktörlerin Belirlenmesi \\ $\ddot{O} Z$}

Amaç: Tatmin edici bir koruyucu ăğz săglı̆g programının geliş̧tirilmesi için, toplumun ağız sağlı̆̆ ile ilgili alışkanlıklarının ve ağız sağlığı durumunun 
bilinmesi gereklidir. Bu bağlamda bu çalışmanın amacl; Uşak ilinde yaşayan Türk toplumunda ăğz sağlı̆̆l tutum ve davranışlarının yanında CPITN ve DMFT indeks değerlerini yaş, cinsiyet ve eğitim durumuna göre değerlendirmektir. Gereç ve Yöntemler: Ăğı sağlı̆̆l davranışlarını anlamak için altı yaş grubuna ayrlan 2412 bireye yüz yüze sorular yöneltildi. Periodontal klinik ölçümler ve diş çürüğü varlığının tespiti kalibre üç periodontolog tarafindan yapıldl. Bulgular: Periodontal olarak sağlıklı birey sayısı sadece 153 kişi $(\% 10,05)$ idi. Bireylerin

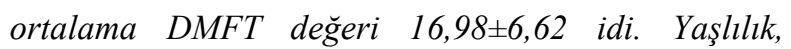
cinsiyetin erkek olmasl ve düşük eğitim seviyesine sahip olma gibi faktörler ortalama DMFT ve CPITN değerlerinde artışa neden olduğu gösterildi. Katılımcıların \%10,26'sı dişlerini firçalamadıklarını bildirdi ve \%92,55'i diş ipi kullanmadıklarını belirtti. Katılımcıların çoğu $(\% 83,25)$ yalnızca acil durumlarda ve ă̆r varlı̆̆ında diş hekimine gittiğini belirtti. Sonuçlar: Ortalama DMFT ve CPITN skorlarl yaşlanma, düşük eğitim düzeyi ve cinsiyetin erkek olması durumlarında arttığl saptandl. Düşük diş ipi kullanma sıklı̆̆l, diş firçalama prevalansının düşük olması ve diş hekimine düzenli gidilme sıklığının yetersiz olduğu belirlendi.

Anahtar Kelimeler: Yaş gruplarl, ăğ sağll̆̆gl, diş firçalama, diş ipi, eğitim.

\section{REFERENCES}

1. Gil-Montoya JA, de Mello AL, Barrios R, Gonzalez-Molesv MA, Bravo M. Oral health in the elderly patient and its impact on general well-being: a nonsystematic review. Clin Interv Aging 2015;10:461467.

2. Loesche WJ, Schork A, Terpenning MS, Chen YM, Dominguez BL, Grossman N. Assessing the relationship between dental disease and coronary heart disease in elderly U.S. veterans. J Am Dent Assoc 1998;129:301-311.

3. Leung WK, Chu $\mathrm{CH}$. Dental caries and periodontal status of 12-year-old school children in rural Qinghai, China. Int Dent J 2003;53:73-78.

4. Selwitz RH, Ismail AI, Pitts NB. Dental caries. Lancet 2007;369:51-59.

5. Enjary C, Tubert-Jeannin S, Manevy R, RogerLeroi V, RiordanvPJ. Dental status and measures of deprivation in Clermont-Ferrand, France. Community Dent Oral Epidemiol 2006;34:363-371.
6. Burt BA, Armitage GC, Cochran DL, Cohen RE, Rethman MP, Van Dyke TE, et al. Position paper, Epidemiology of Periodontal Disease. J Periodontol 1996; 67:935-945.

7. Kassebaum NJ, Smith AG, Bernabé E, Fleming TD, Reynolds AE, Vos T et al. Global, regional, and national prevalence, incidence, and disability-adjusted life years for oral conditions for 195 countries, 19902015: a systematic analysis for the global burden of diseases, injuries, and risk factors. J Dent Res 2017;96:380-387.

8. Ainamo J, Barmes D, Beagrie G, Cutress T, Martin J, Sardo-Infirri J. Development of the world health organization (WHO) community periodontal index of treatment needs (CPITN). Int Dent J 1982;32:281-291.

9. Diego Garcia Bassani, Carina Maciel da Silva, Rui Vicente Oppermann. Validity of the Community Periodontal Index of Treatment Needs' (CPITN) for population periodontitis screening. Cad Saúde Pública 2006;22:277-283.

10. Kidd EA, Fejerskov O. What constitutes dental caries? Histopathology of carious enamel and dentin related to the action of cariogenic biofilms. J Dent Res 2004;83:35-38.

11. Featherstone JD. The continuum of dental caries: evidence for a dynamic disease process. J Dent Res 2004;83:39-42.

12. Vrbic V. Reasons for the caries decline in Slovenia. Community Dent Oral Epidemiol 2000;28:126-132.

13. Ainamo J. Development of the World Health Organization community periodontal index of treatment needs (CPITN). Int Dent J 1982;32:281-291.

14. World Health Organization. Oral Health Surveys Basic Methods. Geneva: WHO publications; 1997.

15. World Health Organization. Oral Health Survey Basic Methods. Geneva: WHO publications; 2013.

16. Miyazaki H, Pilot T, Leclerq M-H, et al. Profiles of periodontal conditions in adults measured by CPITN. Int Dent J 1991;41:74-80.

17. Konig J, B. Holtfreter T. Kocher, Periodontal health in Europe: future trends based on treatment needs and the provision of periodontal services--position paper 1 . Eur J Dent Educ 2010;14:4-24.

18. Petersen PE, Ogawa H. Strengthening the prevention of periodontal disease: The WHO approach. J Periodontol 2005;76:2187-2193

19. Reich, E. Trends in caries and periodontal health epidemiology in Europe. Int Dent J 2001;51:392-398. 
20. Hong-Ying W, Petersen PE, Jin-You B, Bo-Xue Z. The second national survey of oral health status of children and adults in China. Int Dent J 2002;52:283290.

21. Hugoson A, Jordan T. Frequency distribution of individuals aged 20-70 years according to severity of periodontal disease. Commun Dent Oral Epidemiol 1982;10: 187-192.

22. Paulander J, P Axelsson, J. Lindhe. Association between level of education and oral health status in 35-, 50-, 65- and 75-year-olds. J Clin Periodontol 2003;30:697-704

23. Phipps KR, N Reifel, E. Bothwell. The oral health status, treatment needs, and dental utilization patterns of Native American elders. J Public Health Dent 1991;51: 228-33.

24. M Vano, S Gennai, D Karapetsa, M Miceli, MR Giuca, M Gabriele, F Graziani. The influence of educational level and oral hygiene behaviours on DMFT index and CPITN index in an adult Italian population: an epidemiological study. Int $\mathbf{J}$ Dent Hygiene 2015;13:151-157.

25. Burt B. Position paper: epidemiology of periodontal diseases. J Periodontol 2005;76:1406-1419.

26. Furuta M, Ekuni D, Irie K, Azuma T, Tomofuji T, Ogura T, Morita M. Sex differences in gingivitis relate to interaction of oral health behaviors in young people. J Periodontol 2011;82:558-565.

27. Zhu L, Petersen PE, Wang HY, Bian JY, Zhang BX. Oral health knowledge, attitudes and behaviour of children and adolescents in China. Int Dent $\mathbf{J}$ 2003;53:289-298.

28. Rajab LD, Petersen PE, Bakaeen G, Hamdan MA. Oral health behaviour of schoolchildren and parents in Jordan. Int J Pediatr Dent 2002;12:168-176.

29. Maes L, Vereecken C, Vanobbergen J, Honkala S. Tooth brushing and social characteristics of families in 32 countries Int Dent J 2006;56:159-167.

30. American Dental Association (ADA) Division of Science. Keeping your gums healthy. JADA 2015;146:46-47
31. Christensen LB, Petersen PE, Krustrup U, Kjøller M. Selfreported oral hygiene practices among adults in Denmark. Community Dent Health 2003;20:229-235.

32. Payne BJ, Locker D. Relationship between dental and general health behaviors in a Canadian population. J Public Health Dent 1996;56:198-204.

33. Zhu L, Petersen PE, Wang HY, Bian JY, Zhang BX. Oral health knowledge, attitudes and behaviour of adults in China. Int Dent J 2005;55:231-241.

34. Al-Otaibi M, Zimmerman M, Angmar-Månsson B. Prevailing oral hygiene practices among urban Saudi Arabians in relation to age, gender and socio-economic background. Acta Odontol Scand 2003;61:212-216.

35. Akinkugbe A, Lucas-Perry E. Trends in dental visits among the US non-institutionalized civilian population: findings from BRFSS 1995-2008. J Theory Pract Dent Public Health 2013;1:32-36.

36. Olusile AO, Adeniyi AA, Orebanjo O. Self-rated oral health status, oral health service utilization, and oral hygiene practices among adult Nigerians. BMC Oral Health 2014;14:140-141.

37. Unluer S. Oral health status of 35-44 and 65-74 age groups in Turkey 2004. Hacettepe University Institute of Health Sciences, Ph.D. Thesis in Conservative Dentistry Ankara; 2007. 190p.

38. ADA Council on Scientific Affairs. Oral malodour. J Am Dent Assoc 2003;134:209-14.

39. Nadanovsky P, Carvalho LBM, Leon A Ponce De. Oral malodour and its association with age and sex in a general population in Brazil. Oral Diseases 2007;13:105-109.

40. Frexinos J, Denis P, Allemand H, Allouche S, Los F, Bonnelye G. Descriptive study of digestive functional symptoms in the French general population. Gastroenterol Clin Biol 1998;22:785-791.

41. Eren G, Köse T, Atilla G. Determining the oral health status and oral hygiene habits of the elderly. SU Dent J 2011;20:84-92.

42. Baelum V, Pisuithanakan S, Teanpaisan R, Pithpornchaiyakul W, Pongpaisal S, Papapanou PN, Dahlen G, Fejerskov O. Periodontal conditions among adults in Southern Thailand. J Periodont Res 2003;38:156-163. 